\title{
The chances of restorative justice in hate crime cases
}

\author{
VERONIKA SZONTAGH*
}

Centre for Social Sciences Institute for Legal Studies, Hungarian Academy of Sciences Centre of Excellence, Hungary

\section{ORIGINAL RESEARCH PAPER}

Received: February 24, 2020 • Accepted: September 24, 2020

Published online: August 31, 2021

(c) 2020 The Author(s)

\begin{abstract}
This paper discusses whether the methods of restorative justice (RJ), broadly interpreted as alternatives to criminal proceedings and sanctions, are applicable to hate crimes. It builds on the premises that RJ methods are appropriate tools to deal with hate crimes and conflicts that arise from them, as there are social conflicts behind these actions that can be resolved by a sensitive and empathetic approach that focuses on restoration. However, there are dilemmas and factors where caution and an in-depth reflection should be observed to understand how these techniques can work well without further harming either party.
\end{abstract}

\section{KEYWORDS}

hate crime, restorative justice, criminology

\section{INTRODUCTION}

This paper discusses whether the methods of restorative justice (RJ), broadly interpreted as alternatives to criminal proceedings and sanctions, are applicable to hate crimes. It builds on the

\footnotetext{
*Corresponding author. E-mail: Szontagh.VeronikaAnna@tk.hu

The present paper was authored in the framework of the MTA-ELTE Lendület SPECTRA Research Group (Social prerequisites for the effective fight against bias-motivated crimes through criminal law and minority rights protection, contract number: LP2018-9/2018).
} 
premises that RJ methods are appropriate tools to deal with hate crimes and conflicts that arise from them, as there are social conflicts behind these actions that can be resolved by a sensitive and empathetic approach that focuses on restoration. However, there are dilemmas and factors where caution and an in-depth reflection should be observed to understand how these techniques can work well without further harming either party.

This study provides a literature review of dilemmas such as the power balance between the victim and the offender, the perpetrator's prejudiced attitude, and the possibilities of restoring the status quo ante. Debates in criminology, legal and social sciences are increasingly focused on both hate crimes and the use and possible extension of restorative justice so a detailed look into and a reflection on the emerging issues, dilemmas, and opportunities is essential.

According to Nils Christie, a leading Norwegian criminologist, the state has expropriated the possibility of conflict resolution from the communities and people, resulting in the people facing an alien and impersonal retributive justice system. ${ }^{1}$ Restorative justice is a parallel and complementary system to traditional justice which is fundamentally different from the retributive justice in that it interprets crime as a conflict between the persons involved and not in the context of a relationship between the parties and the state. Traditional justice interprets crime as a crime against the state. However, according to the restorative approach, reparation and compensation are not to be expected from and are not the state power's responsibility, but of those in the conflict. This process helps to identify and then re-establish the needs and demands of the parties and to restore damages that had arisen before. Another difference is that the restorative method focuses on the future, emphasizing responsibility and restoration. In contrast, retributive justice is based on past events, it seeks an answer to what has happened, what action has taken place. This gives the basis for the facts that the courts try to reconstruct and the perpetrator is judged based on this act.

The first comprehensive and widely used definition of restorative justice was framed by Tony F. Marshall in 1996

'Restorative Justice is a process whereby parties with a stake in a specific offence collectively resolve how to deal with the aftermath of the offence and its implications for the future.'

Howard Zehr states that the process involves revealing the needs and the harms suffered

'Restorative justice is a process to involve, to the extent possible, those who have a stake in a specific offence and to collectively identify and address harms, needs and obligations, in order to heal and put things as right as possible, ${ }^{3}$

while Braithwaite says it is important to emphasize the goal of restoring social justice, ${ }^{4}$ as the restorative approach revolves around the community and its aim is to strengthen the communal life, which helps to avoid stigmatizing and marginalizing the offender. By relegating the 'violence creates violence' notion to the background, this approach places a much stronger emphasis on developing reintegrative shaming, treating the perpetrator as an important part of the

\footnotetext{
${ }^{1}$ Christie (1977) 1-15.

${ }^{2}$ Marshall (1996) 37.

${ }^{3}$ Zehr (2002) 37.

${ }^{4}$ Braithwaite (2002).
} 
community, with the goal of developing a feeling of responsibility, to allow forgiveness, and reintegration of the offender.

The interlinkage between hate crime and restorative justice has become more significant in recent years, with more scientific publications trying to determine whether restorative methods are a suitable way to deal with serious and complex crimes such as bias crimes, sexual offenses or domestic violence.

The vast literature on restorative justice and hate crime separately is remarkable but the link between the two, as described by Neil Chakraborti ${ }^{5}$ and Mark Walters, ${ }^{6}$ is surrounded by a level of suspicion and distance-keeping by politicians, the public sphere and also the scientific community. In their study, Walters and Carolyn $\mathrm{Hoyle}^{7}$ note that in the debate on hate crime little attention is drawn to the use of restorative methods and their aleatory and potential effectiveness. Many experts consider it important that both side of the arguments and points of view should be better disseminated and analysed and thus facilitating the proper practical implementation of the theoretical framework. ${ }^{8}$

\section{DILEMMAS IN THE COURSE OF THE RESTORATIVE PROCESS}

Theo Gavrielides identifies two possible reasons on why scientific discourse is not more open to this topic. ${ }^{9}$ One of the main reasons is that hate crime is a grey zone for restorative methods, due to the difference in the victim's and the offender's power balance, viz. the offender's ability to exercise control over the victim. ${ }^{10}$ For this reason, many, mostly lobby groups are reluctant to address these procedures because they may revictimize vulnerable victims. ${ }^{11}$ Roxana Willis in her ethnographic research draws attention to another aspect of power imbalance and dominance. ${ }^{12}$ She investigates parties of different backgrounds, social class, ethnicity, intellectual disability, citizenship, coming into the process with different communication or language skills. The process uses the middle class speech form resulting in some parties start off the procedure from the position of an underdog. These communication barriers may cause an imbalance in the $\mathrm{RJ}$ process which is essentially based on verbality and dialogues. RJ procedures should be able to overcome existing power inequalities not to cause further harm to either party.

The main question is can restorative methods ensure equal opportunities during the procedures?

The second reason identified by Gavrielides poses a more abstract challenge for researchers. One of the reasoning's key elements is the restoration of the status quo ante, which requires further investigation in the case of hate crimes. An important part of restorative justice

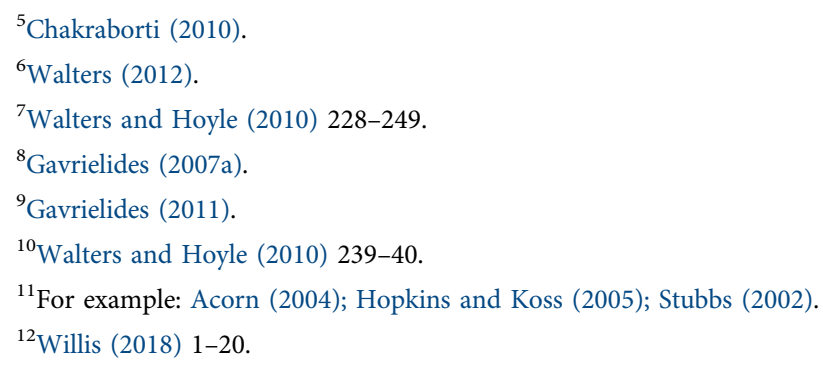


procedures is to create a situation as if the crime had never happened. This is, for example, well understood in the cases of crimes against property, but George Pavlich is sceptical about what the restorative approach can achieve for the community. ${ }^{13}$ On the other hand, Walters et al. argue that the true purpose of recovery needs to be re-evaluated in the case of hate crimes. ${ }^{14}$ They believe that the goal in these cases is rather to eliminate bias, stereotypes and to promote the cultural differences, and Gavrielides sees the process itself as a form of compensation for the victim. ${ }^{15} \mathrm{He}$ also points out that community restoration can have a positive effect in the long run, but only if the victims are able to overpower their utilitarian approach.

Furthermore, the question of what a 'good' or an 'ideal' victim looks like needs to be examined. If imaginary victims are always forgiving and behaving as pious, benignant, non-vengeful persons, then yes, they may be able to transcend the utilitarian approach, subordinating their behaviour to the greater good of forgiveness. In this case, according to George Fletcher, the victims are similar to Jesus Christ, the sacrificial Lamb of God, whose name and identity were first associated with the original Latin phrase for the victim, victima sacrificial animal and who forgave and asked for forgiveness. ${ }^{16}$ Fletcher in Grammar of Criminal Law ${ }^{17}$ and victimologist Jan van Dijk have extensively studied the etymology of the word 'victim' and the role of victims in crime situations and criminal procedures. According to Ybo Buruma, ${ }^{18}$ the increasingly important role of the victims in the procedures demonises the offender proportionally which makes restoration more difficult. Creating and maintaining balance is one of the key points. Are victims really so pious and forgiving? According to Nils Christie, restorative justice often sees and lets the victims be seen in this dignified manner nurturing a strong sense of forgiveness, which can bring comfort and peace not only to their lives but also to the community. ${ }^{19}$ In many cases, this expectation is unrealistic because either the seriousness of the crime or the perpetrator's attitude prevents or makes it difficult to forgive them, as explained in Christie's study. As a result, victims blame themselves for not being able to move forward, furthermore even their social circle's empathy and solidarity may diminish due to the victim's inability to forgive. ${ }^{20}$ Portraying an 'ideal' victim and the pressure to behave accordingly may often pose a barrier to the victim's anger and revenge. In the 1980s, the rediscovery of victims and the extension of victims' rights, as well as the restorative approach may have helped the victim to experience their anger, but also to forgive the perpetrator.

To this end, the majority of authors emphasize the prominent role and importance of the facilitator, as an effective communication; a secure environment; impartiality and preparedness as crucial factors to tackle this sensitive issue. David Smith argues that a mutually beneficial agreement is possible even if the victim is unable to overcome the utilitarian attitude or desire for vengeance, but this is unlikely to contribute to the individual and social changes, the creation

\footnotetext{
${ }^{13}$ Pavlich (2004) 173-83.

${ }^{14}$ Walters and Hoyle (2010) 231.

${ }^{15}$ Gavrielides (2007b).

${ }^{16}$ Jesus said, 'Father, forgive them; they do not know what they are doing. ' Luke 23,34.

${ }^{17}$ Fletcher (2007).

${ }^{18}$ Buruma (1996) The title of this inaugural lecture given at the University of Nijmegen: 'De Aandacht van de Strafrechter' can be translated as 'The Attention of the Criminal Judge.'.

${ }^{19}$ Christie (1986).

${ }^{20}$ van Dijk (2008) 13-24.
} 
of a better society, strengthening communities and reducing the number of serious crimes such as hate crime. ${ }^{21}$ Richard Delgado sees the issue similarly, although he expresses doubts on whether one or more in-person encounters could facilitate the offender's moral development, self-reflection, and even thinks that it is an idealistic idea for a prejudiced, racist person to become empathic or even tolerant only by having finished the restorative process. Delgado bases his reasoning on the fact that the perpetrator's prejudiced attitude or even their biased environment has been an integral part of their personality and life for a long time. ${ }^{22}$ This is also acknowledged by Walters et al. but they believe that it is worthwhile to use restorative justice tools even if it only changes one offender's attitude. ${ }^{23}$ In this context, they also claim that providing the perpetrator with the opportunity to meet someone face to face against whom they are prejudiced, in a safe environment without peer pressure and the company of others that might provoke them, could help in discovering the origin of their bias and the reasons behind it.

Another aspect of this issue is that the acts of prejudiced perpetrators generally have deeprooted causes and motivations and are therefore less prone to and suitable for community-based restorative approaches. The question is whether the perpetrators could be engaged in honest and open conversations about their prejudice. When social hatred emerges, the perpetrator believes that the victim has less political and economic power than the majority but nevertheless the victims and their communities are a threat to their economic, political and cultural status. ${ }^{24}$ Offenders may use neutralization techniques to deny or diminish the severity and extent of their acts and/or violence, the extent of victimization and even victim blaming emerges which may contribute to the offenders' deflecting responsibility. ${ }^{25}$ The basic premise of the theory is that the members of society have an internal moral obligation to avoid illegitimate acts. If someone does commit a criminal act, they may use these strategies to reduce internal moral distress, guilt, and to legitimate their acts. It should be emphasized amongst the neutralization techniques, from the point of view of the subject discussed, how the offender considers the victim. In some cases, the perpetrator believes that the victim is a less valuable person, not worthy of respect and the perpetrator may even dehumanize them. Research on the Rwandan genocide has also identified two new neutralization techniques. ${ }^{26}$ One is that the perpetrator poses as the 'good guy' in an attempt to reinforce the notion that they are incapable of committing such a serious act. The other technique is when the perpetrator is also in a victimized situation and they justify their actions or those of their family or persons of the same ethnic group because of threat, pressure and fear. ${ }^{27}$

These neutralisation techniques, according to Walters may well occur but a well-trained and well-prepared mediator or facilitator can handle the situation and in Walters' view, it is still the restorative process which can mitigate the effects of neutralization in the best way possible. It is more difficult for an offender to deny the consequences of their actions if confronted with an

\footnotetext{
${ }^{21}$ Smith (1995).

${ }^{22}$ Delgado (2000).

${ }^{23}$ Walters and Hoyle (2010). 233-35.

${ }^{24}$ Krémer (2013) 20-35.

${ }^{25}$ Sykes and Matza (1957).

${ }^{26}$ Bryant et al. (2017) 1-19.

${ }^{27}$ Previous studies, analyzes of genocide and the explanation of neutralization techniques have been conducted, for example: Alvarez (1997) or Neubacher (2006).
} 
injured and traumatized victim whose behaviour and story is likely to affect them. ${ }^{28}$ Eliminating and overcoming neutralization techniques can have a positive effect and the perpetrator may help to prevent the victim from blaming themselves which is a common feature among victims of bias motivated crime. ${ }^{29}$ Reflecting on the effects of neutralization, the offender may also deny having any prejudice which mostly occurs in mixed-motive crimes. The issue of mixed-motive hate crimes is also important because many of these types of acts occur in everyday life situations and routines where prejudice is not the main driver of the act. These acts are mainly motivated by frustration and anger therefore they mostly focus on the victim's vulnerability and being different, attacked and offended more easily, than on prejudice..$^{30,31}$

Another question is how restorative justice can be conceptualized in the context of hate crime. Mark Umbreit et al. believe that restorative justice provides a completely different interpretative framework for understanding intolerance and racist violence. ${ }^{32}$

The topic is currently under-researched but there is awareness of practical uses of restorative justice techniques in the hate crime context. Several studies point out that after the Rwandan genocide, the Gacaca justice was operating in a restorative manner. Alana Tiemessen emphasizes that Gacaca is a model of restorative justice as it focuses on the feelings of victims and perpetrators, confessions, reconciliation and reintegration. ${ }^{33}$ In addition, several programs and pilot projects work in practice, most of them involving the actors of the traditional judicial process. By analysing and examining these programs, theoretical dilemmas can be better understood and even resolved. Several restorative procedures have been documented in the United States and the United Kingdom and these cases highlight the potential of restorative justice in solving hate crimes and underline the effectiveness of RJ. Some authors believe that this type of procedure is much more capable of resolving social conflict and minimizing harm to the victims and their communities than the traditional justice system. ${ }^{34}$ Walters argues that the restorative process gives the victim strength and control to verbalize their feelings freely and openly. In addition, this gives marginalized minorities or vulnerable groups a chance to make their voices heard that had previously been suppressed due to their social status. ${ }^{35}$

Walters also points out that retributive justice is not expected to treat the social structure's symptoms leading to crime. Efforts should be made to build an inclusive society, for example through a wider use of restorative justice which could reduce the social divide. Restorative justice cannot deal with hate crimes alone but it can be an effective tool for efficiently addressing the complex causes and consequences of hate crimes. ${ }^{36}$ Gavrielides explains that a restorative

\footnotetext{
${ }^{28}$ Walters (2014).

${ }^{29}$ Walters (2014).

${ }^{30}$ Walters (2018).

${ }^{31}$ In Hungary, as a result of a hate crime research conducted by Petra Bárd at the National Institute of Criminology it can be stated that many acts were trivial in an everyday situations: between neighbors, in a pub or on public transport (Bárd (2015)). This is confirmed by the Equality and Human Rights Commission Research Report 102: Causes and Motivations of Hate Crime. Report 2016, which categorizes 'everyday hate crimes'.

${ }^{32}$ Umbreit et al. (2003).

${ }^{33}$ Tiemessen (2004) 57-76.; Hauschildt (2012); McKenna (2006).

${ }^{34}$ Umbreit et al. (2003); Gavrielides (2007b); Walters and Hoyle (2010); Walters (2012).

${ }^{35}$ Walters (2014).

${ }^{36}$ Walters (2018) 24.
} 
procedure may not be the most appropriate option in the case of more serious hate crimes, as victims may fear further victimization or trauma during in-person mediation. This may be true in the case of minor offenses e.g. racist graffiti, vandalism, egg-throwing or name-calling, as these acts can have a stronger and lasting impact than base crime on the victim and their community. ${ }^{37}$ According to Walters, the traumatic effect also involves the victim being in a marginalized position and this social inequality amplifies the victimization effect of the particular crime. ${ }^{38}$ Both authors believe that restorative justice can balance the rights and needs of the victim and the offender regardless of their gender, ethnicity, religion, and so on. In addition, the restorative approach is based on respect, mutual understanding, inclusiveness or volunteering. These values may reduce prejudice.

The most striking and controversial dilemma is whether restorative methods can build intercultural bridges, which are essential for social inclusion. In a multicultural society, different cultural backgrounds, the victim's, the perpetrator's, the facilitator's, may carry the risk of misunderstanding, talking about contrary directions or even further victimization. Authors who take a positive view on the issue emphasize the importance of empathy. One of the main goals of a restorative meeting is for the perpetrator to understand the victim's cultural background, religion, origin, etc., which requires empathy but the reverse is also needed; an empathetic attitude is required for the victim to be able to listen to the offender's story and motivation. Empathy can be a catalyst for a change in personality attitudes that can benefit not only the victim directly but also the wider community. Karen Smith's work formulates the concept of 'empathic division'. ${ }^{39}$ This can emerge when the parties have different backgrounds, which makes it difficult to develop a sense of understanding with a person belonging to a different group. The right way to overcome 'empathic division' is that in addition to the physical and/or psychological damage, the offender should be able to treat the victim and their community as 'human'. Conversely, social distance can query the effectiveness of restorative justice. ${ }^{40}$

It is worth to further explore the question of how in-person encounters can influence prejudice. Sociological research has long been seeking an answer to the question whether personal acquaintance reduces or increases prejudice. Research shows that prejudice significantly depends on which minority group examined and where the event occurs. Endre Sik and Blanka Dencső show in their research that the presence of a Roma acquaintance increases the likelihood of prejudice in an urban setting but prejudice decreases in villages. ${ }^{41}$ Another important finding of the research from this topic's point of view is that if the degree of prejudice is low, the power of personal relationships reduces the prejudice. However, if the level of prejudice is high, then a larger group e.g. a city, only increases the potential of conflicts because of the larger chance of creating an impersonal stereotype. Conversely, in spite of the high level of prejudice in a smaller group, conflicts are more personal, as Sik-Dencső put it, they are 'human-faced', so it is easier to reduce both conflict and prejudice. Linking the above research findings to the topic of RJ provides a better understanding which are the conflicts that restoration may help resolve. Of

\footnotetext{
${ }^{37}$ Gavrielides (2007b).

${ }^{38}$ Walters (2014).

${ }^{39}$ Smith (2006).

${ }^{40}$ Kelly (2002).

${ }^{41}$ Dencső and Sik (2007).
} 
course, it should be noted that personal contact takes place in a special setting as it was preceded by a crime. The role of the facilitator in this issue is significant too because if someone understands and is able to deal with cultural, religious, and identity differences then social change can be achieved step by step. Similarly, if differences, control- or dominance issues or suspicion prevail during the mediation, they will undoubtedly affect the effectiveness of the mediation. ${ }^{42}$

\section{DILEMMAS IN ALTERNATIVE SANCTIONS}

In addition to restorative procedures, alternative sanctions can also replace traditional legal consequences. Some alternative punishments may be based on a restorative approach and may aim to sensitize offenders and break down their prejudice or ignorance. Alternative sanctions and community-based penalties help to avoid the detrimental effects of incarceration and as they are built on the foundations of community reception, all of these factors can reduce the risk of recidivism and increase the effectiveness of the sanction. ${ }^{43}$ Community-based sanctions have three characteristics: they are enforced in the community setting; contain elements of restriction of liberty and support and there is a continuous and active personal connection between the perpetrator and the enforcer of the sanction during the enforcement period. ${ }^{44}$ Sanctions of this kind have the same purpose as traditional punishments: to prevent recidivism and to protect society. In order to do this, the Hungarian probation service facilitates the social reintegration of the offenders. Probation service has both punitive and social traits to help strike a balance between support and control.

It is important to note that restorative justice methods and procedures discussed earlier fall into the category of diversion. Their purpose is to replace criminal proceedings. However, in the case of alternative sanctions, the non-custodial sentence in the judgement is enforced within the community setting under the supervision of the probation service. In Hungary, probation is an additional legal consequence; one of its important elements is compliance with the rules of conduct. There may be general rules of conduct or special/additional rules of procedure prescribed by the prosecutor or judge, allowing to include the restorative approach.

In December 2013, three men in their twenties, damaged the menorahs all over Budapest displayed to celebrate Hanukkah. On December 11, 2014, a first-instance verdict was issued stating that all three were sentenced to imprisonment for the act of vandalism resulting in the destruction of religious objects and for public nuisance. The sentence was suspended for two years. In its judgment, the court ordered the offenders to read two specific books on Romas and Jews and to make reading diaries of the books as an additional rule of conduct. ${ }^{45}$

Such convictions are not limited to juveniles. A judgment that became legally binding on January 31, 2013 resulted in a man convicted of Holocaust denial being sentenced to a suspended incarceration and ordered to make three visits to the Holocaust Memorial Centre in Budapest and write a summary essay about the visitations. ${ }^{46} \mathrm{~A}$ similar verdict was issued on

\footnotetext{
${ }^{42}$ Walters and Hoyle (2010) 240-41.

${ }^{43}$ Kerezsi (2016) 908.

${ }^{44}$ Kerezsi (2016) 909.

${ }^{45}$ Pálmai (2015).

${ }^{46}$ Pálmai (2015).
} 
April 16, 2015, when the Szeged District Court sentenced a woman on probation for Holocaust denial and ordered her to visit the Memorial Centre as a special rule and to read a book by historian László Karsai on Holocaust. ${ }^{47}$

There are dilemmas not only in the restoration process but also regarding the enforcement of alternative sanctions. One of the most important questions is whether such sanctions and rules of conduct help to sensitize offenders and prevent recidivism. Gendreau et al., studying the effectiveness of intensive probation, found that recidivism rates could increase by 7 percent if these rules of conduct do not include treatment elements. Those programs which contained a strong and intense component of treatment could reduce the recidivism rate by 10 percent. The above examples show that other goals are met such as reducing the lack of knowledge or changing misconceptions.

\section{SUMMARY}

'Most of the prejudiced people have severe lack of knowledge, and it would help a lot to get good quality information, to discuss their beliefs and prejudices'

Hungarian sociologist Mária Herczog wrote about the vandalism of the menorahs and expresses her agreement with the imposition of alternative sanctions. ${ }^{48}$ This quote also confirms that restorative methods have great potentials to resolve prejudicial crimes. Nevertheless, the literature review sheds light on how divided scientific discourse is on this topic. The least dividing issue is that restorative justice is an inclusive procedure holding the right tools to play a role in dealing with hate crimes. The issue however displays rather divided opinions on whether restorative procedures are able to address the causes and the social and community consequences of hate crimes. Prejudice, social hatred, strong victimization of the victims, as well as the attitude of the perpetrators are all complex issues that need to be reflected in the preparation of the restorative process and throughout the whole procedure as well. Much of the literature highlights the prominent role of the facilitator. Facilitators need to be well-prepared and welltrained in such sensitive issues to be able to handle the reactions and behaviours of victims and perpetrators of different backgrounds. Existing programs and pilot projects ${ }^{49}$ have shown encouraging results in combatting recidivism and can provide a good example for any organizations, initiatives where it is still in its infancy or states where the legislator or law enforcement is not open to the issue. This can also be seen in Hungary where the legislator has created the opportunity but law enforcers refuse to refer bias crimes to mediation. ${ }^{50}$

\footnotetext{
${ }^{47}<$ https://tev.hu/jogeros-itelet-holokauszttagadasert/> accessed 15 December 2020.

${ }^{48}$ Pálmai (2015).

${ }^{49}$ More in detail: Walters (2014) Chapter 4.

${ }^{50}$ According to the Hungarian Criminal Code, the basic fact of Violence Against a Member of the Community could be referred to mediation however, the prosecution and court do not use mediation in such cases. This position is expressed in Circular Letter of No. 4/2013 (VI. 30.) of the Deputy Prosecutor General for Criminal Law. The above-mentioned circular letter argues that the state's criminal law enforcement needs to be more effectively enforced for crimes that are particularly dangerous to society. In particular, it points out that, in these cases, a penalty item approaching or reaching the upper limit of the penalty should be regarded as a legal consequence.
} 
The main purpose of both alternative sanctions and community-based sanctions are crime prevention, retention, reintegration of the offender, repentance and forgiveness. From the point of view of hate crime sensitization, reducing ignorance and eliminating prejudice are also key objectives. These are not low expectations towards the restorative approach and its methods but their fulfilment is essential in resolving social conflicts. Many programs and procedures of international organizations and NGOs have mutual goals, some of them aim to achieve sensitization in prison institutions. ${ }^{51}$ Instead of moral judgment, understanding and acceptance are of high priority paving the way for successful sensitization. One of the characteristic elements of the restorative approach and alternative sanctions is to think in terms of the community since this is the way to familiarize with different points of view and to engage participants in a constructive dialogue reflecting on each other's feelings and experiences. It is important to create a climate of trust and to deal with aggressive behaviour, which is the facilitator's responsibility, so it is important that the person who meets the parties after a prejudicial act is well-trained and prepared.

One of the essential elements of most procedures and programs is the educational objective, - to make the perpetrator aware of cultural diversity and to make them face their prejudice. In many cases hate crimes are caused by ignorance, so education, in addition to restoration is fundamental to a future result of reduced recidivism. Reflecting on the presented examples, it would be interesting to know whether the books and reading diaries had been processed by the perpetrators with their probation officers or whether there was someone they had been able to talk to about the books and their contents. Such an additional rule of conduct has a meaning and effect when it is not only a task to be completed but also to be mentally processed so that the offender understands why they had to do it. In addition, there is a need for appropriate legal bases which exist in Hungary for the mediation process and alternative sanctions but it would be worthwhile in the future to open up to various non-governmental initiatives and organizations that are experienced and well-prepared to deal with crimes of prejudice.

\section{LITERATURE}

Acorn, A., Compulsory compassion: A critique of restorative justice (UBC Press 2004).

Alvarez, A., 'Adjusting to Genocide: The Techniques of Neutralization and the Holocaust' (1997) 2 Social Science History 139-78.

Bárd, P., 'A gyülölet-büncselekmények büntetőjogi üldözésének jogszabályi és társadalmi feltételrendszere'

(Legal and social prerequisites for the criminal prosecution of hate crimes) (2015) 75 Kriminológiai Közlemények 93-154.

Braithwaite, J., Restorative Justice and Responsive Regulation (OUP Press 2002).

Bryant, E. et al., 'Techniques of Neutralization and Identity Work Among Accused Genocide' (2018) 4

Social Problems 584-602.

Buruma, Ybo (1996) De Aandacht van de Strafrechter (The Attention of the Criminal Judge) (Gouda Quint 1996).

${ }^{51}$ For more details on the programs, see Ignaski et al. (2011). 
Chakraborti, N., Hate Crime: concepts, policy, future directions (Willan Publishing 2010).

Christie, N., 'Conflicts as Property' (1977) 1 British Journal of Criminology 1-15.

Christie N., 'The Ideal Victim' in Fattah, E.A. (ed), From Crime Policy to Victim Policy (Palgrave Macmillan 1986) 17-30.

Delgado, R., 'Goodbye to Hammurabi: Analyzing the Atavistic Appeal of Restorative Justice' (2000) 4 Stanford Law Review 751-75.

Dencső, B. and Sik, E., 'Adalékok az elóítéletesség mértékének és okainak megismeréséhez a mai Magyarországon' (Data to recognize about the extent and causes of prejudice of Hungary) (2007) 1 Educatio 50-66. <https://folyoiratok.oh.gov.hu/educatio/adalekok-az-eloiteletesseg-mertekenek-es-okainakmegismeresehez-a-mai-magyarorszagon $\geq$ accessed 15 December 2020.

van Dijk, J. J. M., 'In the shadow of Christ? On the use of the word "victim" for those affected by crime' (2008) 13 Criminal Justice Ethics 13-24.

Equality and Human Rights Commission, Research report 102, Causes and Motivations of Hate Crime (Equality and Human Rights Commission 2016).

Fletcher, G., The Grammar of Criminal Law: American, Comparative, and International, vol. 1: Foundations (OUP 2007).

Gavrielides, T., Restorative justice theory and practice: Addressing the discrepancy (HEUNI 2007a).

Gavrielides, T., Restoring relationships: Addressing hate crime through restorative justice (Race on Agenda Report 2007b).

Gavrielides, T., 'Restorative practices \& hate crime: Opening up the debate' (2011) 4 Temida 7-20.

Hauschildt, T., 'Gacaca Courts and Restorative Justice in Rwanda' (2012) E-International Relations. $<$ https://www.e-ir.info/2012/07/15/gacaca-courts-and-restorative-justice-in-rwanda/> accessed 15 December 2020.

Hopkins, C. Q. and Koss, M., 'Incorporating feminist theory and insights into a restorative justice response to sex offences' (2005) 5 Violence Against Women 693-723.

Ignaski et al., Rehabilitation of Hate Crime Offenders (Research Report 2011).

Kelly, T., 'Is Restorative Justice Appropriate in Cases of Hate Crime' (conference paper) (2002) Western Pacific Association of Criminal Justice Educators Conference, Lake Tahoc, Nevada.

Kerezsi, K., 'Alternatív szankciók és közösségben végrehajtott büntetések' (Alternative sanctions and community-based punishments) in Borbíró, A. et al. (eds), Kriminológia (Wolters Kluwer 2016) 908-27.

Krémer, F. 'A társadalmi gyülölet és a gyülölet-büncselekmények kezelése' (Dealing with social hostility and hate crimes) (2013) 12 Belügyi Szemle 20-35.

Marshall, T. 'The evolution of restorative justice in Britain'. European Journal on Criminal Policy and Research (1996) 4, 21-43.

McKenna, K., 'Gacaca - A Paradigm for Restorative Justice in Rwanda' (2006) 5 Trinity College Law Review.

Neubacher, F., 'How Can It Happen that Horrendous State Crimes are Perpetrated? An Overview of Criminological Theories' (2006) 4 Journal of International Criminal Justice 787-99.

Pálmai, E. 'Formabontó ítéletek' (Unconventional judgements) (2015) 4 HVG 18-20. <https://ujbtk.hu/ formabonto-iteletek/> accessed 15 December 2020.

Pavlich, G., 'What are the Dangers As Well As the Promises of Community Involvement?' in Zehr, H. and Toews, B. (eds), Critical Issues in Restorative Justice (Criminal Justice Press and Willan Publishing 2004) 173-83.

Smith, D., Criminology for Social Work (Macmillan 1995).

Smith, K., 'Dissolving the Divide: Cross Racial Communication in the Restorative Justice Process' (2006) 15 Dalhousie Journal of Legal Studies 168-203. 
Stubbs, J., 'Domestic violence and women's safety: Feminist challenges to restorative justice' in Strang, H. and Braithwaite, J. (eds), Restorative justice and family violence (CUP 2002) 42-61.

Sykes G.M. and Matza, D., 'Techniques of Neutralization: Theory of Delinquency' (1957) 6 American Sociological Review 664-70.

Tiemessen, A. E., 'After Arusha: Gacaca justice in post-genocide Rwanda' (2004) 1 African Studies Quarterly 57-76.

Umbreit, M., Lewis, T. and Burns, H., 'A Community Response to a 9/11 Hate Crime: Restorative Justice through Dialogue' (2003) 4 Contemporary Justice Review 383-91.

Walters, M., 'Hate crime in the UK: promoting the values of dignity and respect through restorative justice' in Gavrielides, T. (ed), Rights and Restoration Within Youth Justice (de Sitter Publications 2012) 335-66.

Walters, M., (2014) Hate Crime and Restorative Justice. Exploring Causes, Repairing Harms (OUP 2014).

Walters, M., 'Readdressing Hate Crime: Synthesizing Law, Punishment and Restorative Justice' in Brudholm, T. and Johansen, B. (eds), Hate, politics, law (OUP 2018) 150-71.

Walters, M. and Hoyle, C., 'Healing harms and engendering tolerance: The promise of restorative justice for hate crime' in Chakraborti, N. (ed), Hate crime: Concepts, policy, future directions (Willan 2010) 228-49.

Willis, R. 'Let's talk about is': Why social class matters to restorative justice' (2018) 2 Criminology and Criminal Justice 1-20.

Zehr, H., The Little Book of Restorative Justice (Good Books 2002).

Open Access. This is an open-access article distributed under the terms of the Creative Commons Attribution 4.0 International License (https://creativecommons.org/licenses/by/4.0/), which permits unrestricted use, distribution, and reproduction in any medium, provided the original author and source are credited, a link to the CC License is provided, and changes - if any - are indicated. (SID_1) 